\title{
Çukurova Üniversitesi Yerleşkesinde Artan Yapılaşmanın Floraya Etkisinin Belirlenmesi
}

\author{
Muzaffer YÜCEL ${ }^{1}$ Zerrin SÖĞÜT ${ }^{2}$ Necattin TÜRKMEN ${ }^{3}$ Deniz ÇOLAKKADIOĞLU ${ }^{\&}$ Barış KAHVECİ \\ Veli ÇELIKTAŞ6 \\ 1,2,5Çukurova Üniversitesi, Mimarlık Fakültesi, Peyzaj Mimarlığı Bölümü, 01330 Sarıçam ADANA, ${ }^{3,6}$ Çukurova Üniversitesi, Fen Edebiyat \\ Fakültesi, Biyoloji Bölümü, 01330 Sarıçam ADANA, ${ }^{4}$ Hatay Mustafa Kemal Üniversitesi, Mimarlık Fakültesi, Peyzaj Mimarlığı Bölümü, \\ 31100 HATAY \\ ${ }^{1}$ https://orcid.org/0000-0002-7269-6719, ${ }^{2}$ https://orcid.org/0000-0002-0000-6272, ${ }^{3}$ https://orcid.org/0000-0002-7185-5896 \\ ${ }^{4} \mathrm{https}: / /$ orcid.org/0000-0002-2946-2036, ${ }^{5} \mathrm{https}: / /$ orcid.org/0000-0002-8508-1748, ${ }^{6} \mathrm{https}: / /$ orcid.org/0000-0001-7753-1422 \\ $\bowtie$ : dcolakkadioglu@gmail.com
}

\section{ÖZET}

Türlerin korunması amacıyla dünyada kabul görmüş birincil strateji korunan alanların ilanıdır. $\mathrm{Bu}$ kategorilerin dışında devlet kurumlarının bulunduğu alanlar ya da Çukurova Üniversitesinde olduğu gibi, üniversite yerleşkeleri de biyolojik çeşitliliğin korunduğu/korunabileceği önemli alanlardır. Araştırma alanını oluşturan Çukurova Üniversitesi Yerleşkesi, 1977.26 hektarlık bir alanı kapsamaktadır. Bu alan zengin biyolojik çeşitliliğge sahip olmasına rağmen, artan yapılaşma süreci tehdidi altındadır. Bu gerçekten hareketle çalışmanın amacı, Çukurova Üniversitesi Yerleşkesinde artan eğitim öğretim dokusu kapsamındaki yapılaşmaların flora üzerine etkilerinin belirlenmesidir. Amacı doğrultusunda araştırmada ilk olarak yerleşkenin 1987 yılı ile 2018 yılı alan kullanımları ArcGIS 10.0 bilgisayar yazılımı ile sınıflandırılmıştır. Arazi çalışmaları kapsamında elde edilen veriler doğrultusunda bitkiler, öncelikle Raunkiaer'in hayat formlarına göre sınıflandırılmış, yerleşkede endemizm oranı saptanmış ve daha sonra yerleşkenin antropojenik değişim derecesi saptanmıştır. Başta endemik türler olmak üzere birçok bitki türü için habitat olan alanların eğitim öğretim dokusu için yapılaşmaya açıldığı belirlenmiştir.

\section{Determination of the Effect of Increasing Settlement on Flora in Çukurova University Campus}

\section{ABSTRACT}

The primary strategy adopted in the world for the protection of the species is the declaration of protected areas. Besides these categories, university campuses like Çukurova University are also important areas where biological diversity can be protected / maintained, as well as in areas where government institutions are located at. Çukurova University Campus, which constitutes the research area, covers an area of 1977.26 hectares. Although this area has rich biodiversity, it is threatened by an increased structuring process. The aim of this study is to determine the effects of the buildings on the flora of the Çukurova University Campus in the context of increased education and training. In line with its objective, the campus' 1987 land uses and 2018 land uses were classified by ArcGIS 10.0 computer software. In line with the data obtained in the scope of area studies, plants were classified primarily according to the life forms of Raunkiaer, was determined to the rate of endemism on campus, and then the degree of anthropogenic change of the campus was determined. It has been determined that the areas that are habitats for many plant species, especially endemic species, are opened to construction.

\section{Araştırma Makalesi}

Makale Tarihçesi
Geliş Tarihi $\quad: 18.03 .2019$
Kabul Tarihi

\section{Anahtar Kelimeler}

Biyolojik çeşitlilik

Raunkiaer'in hayat formları

Synantropizm indeksi

To Cite : Yücel M, Sögüt Z, Türkmen N, Çolakkadıŏlu D, Kahveci B, Çeliktaş V 2019. Çukurova Üniversitesi Yerleşkesinde Artan Yapılaşmanın Floraya Etkisinin Belirlenmesi. KSÜ Tarım ve Doğa Derg 22(Ek Sayı 2): 310-322. DOI: 10.18016/ ksutarimdoga.vi.541325. 


\section{GİṘŞ}

Hızla gelişen teknolojinin bilinçsiz kullanımı, sanayi devrimi ile fosil yakıt kullanımındaki artış, artan nüfus ve buna paralel olarak artan ve değişen tüketim alışkanlıkları ile kentleşme gibi insan etkinlikleri sonucu dünyada var olan doğal denge, doğanın aleyhinde hızla değişmektedir (Yücel, 2005). Söz konusu olumsuz değişimler ilk başlarda hava, su, toprak ve gürültü kirliliği gibi çeşitli çevre sorunları ile sonuçlanırken; günümüzde türlerin ve yaşam alanlarının varlığının tehlikeye girmesi ve/veya yok olması olarak ciddi boyutlara ulaşmıştır.

Doğada süregelen insan baskısının olumsuz etkilerini önlemek amacıyla türlerin ve yaşam alanlarının, buna ek olarak kültürel, jeolojik, arkeolojik ve tarihi değerlerin korunması gerekliliği fikri oluşmuştur (Demirel, 2005). Bu fikir gereği oluşturulan korunan alanlar Gülez (1992)'in de belirttiği gibi, tehlike altında, nadir ve ender bulunan türler ile yaşam alanlarının korunmasını sağlayarak; dünyadaki ekolojik dengenin ve süreçlerin devamlılığını garanti altına almayı amaçlamaktadır. Söz konusu amacın gerçekleştirilmesinde ise korunan alanların sayıca ve alansal olarak arttırılması tüm ülkelerce birincil strateji olarak kabul edilmiş ve 100 yılı aşkın bir süredir birbirinden farklı koruma kategorileriyle korunan alanlar ilan edilmiştir (Chape ve ark., 2005; Liu ve ark., 2010; Lu ve Qu, 2018, Hummel ve ark., 2019).

Kültürel ve biyolojik çeşitlilik açısından çok zengin olan ülkemizde ise biyolojik çeşitlilik, milli parklar, doğa koruma alanları ve doğal sitler gibi 10 farklı kategoride 60 yılın üzerinde bir süredir korunmaktadır. 27 Aralık 1996 tarihinde Biyolojik Çeşitlilik Sözleşmesi'ne de taraf olan ülkemizde, biyolojik çeşitliliğin korunması amacıyla gerçekleştirilen alansal koruma çalışmaları, korunan alanların sayıca arttırılmasıyla devam etmektedir. Ancak biyolojik çeşitliliğin korunmasında sadece koruma altına alınmış alanlar değil, henüz bir koruma statüsü olmayan, buna rağmen yüksek düzeyde biyolojik çeşitliliğe sahip olup korunması gerekli alanlar da bulunmaktadır. Ülkemizde özellikle devlet kurumlarının bulunduğu alanlar ve Çukurova Üniversitesi Yerleşkesi gibi üniversite yerleşkeleri de doğru planlama süreci ile biyolojik çeşitliliğin korunmasına katkı sağlayacak önemli alanlardandır.

Araştırmaya konu olan Çukurova Üniversitesi Yerleşkesi, Adana kentinin kuzeyinde Seyhan Baraj Gölü kıyısında yer alması, sınırları içinde değişken topografik yapı özelliklerine sahip olması, Yaban Hayatı Geliştirme Sahası sınırları içerisinde yer alması ve en önemlisi de kentleşme baskısından korunmuş olması gibi nedenlerle biyolojik çeşitlilik açısından oldukça zengindir. Yerleşkenin doğal yapısı kapsamında yapılan önceki çalışmalar da yerleşkenin zengin biyolojik çeşitliliğini kanıtlamıştır. Yerleşkenin ilk kurulduğu yıllarda Türkmen (1987) tarafından yapılan araştırma sonuçlarına göre yerleşkede 67 familya ve 265 cinse ait 415 bitki türü saptanmış, ayrıca türlerin habitat ve yaşam formları açısından çeşitliliğine de vurgu yapılmıştır. Ünal (1995), doğal bitki örtüsünün rejenerasyon süreci içerisinde ortaya çıkan bitki taksonlarının sosyolojik özellikleri konusunda detaylı araştırmalar gerçekleştirerek, yerleşkedeki ağaçlandırma alanlarını; ibreli türler ve yapraklı türler olmak üzere iki sınıfta saptamıştır. Göçük (1996) ise gerçekleştirdiği araştırmasında yerleşkenin soğanlı, yumrulu ve rizomlu türler bakımından da zenginliğini ortaya koymuştur. Gövrek (1997); Altunkasa ve ark. (1999) ise gerçekleştirdikleri çalışmalarında yerleşkenin doğal potansiyelini belirleyerek, bu potansiyel kapsamında farklı biyotop özellikleri gösteren alanların çeşitliliğini ortaya koyarak, bu alanların biyolojik çeşitlilik için önemini vurgulamışlardır. Darıcı ve ark. (2016) ise dünyanın pek çok ülkesini temsil eden ağaç ve çalıların Çukurova Üniversitesi Yerleşkesinde yetiştiğini belirttikleri çalışmalarında yerleşkenin bir botanik bahçesi kadar zengin olduğunu belirtmişlerdir.

Ülkemizin biyolojik çeşitlilik açısından en önemli yerleşkelerinden biri olan Çukurova Üniversitesi, her yıl açılan yeni fakülteler ve buna bağlı olarak artan karayolu ulaşım ağı nedeniyle önemli bir yapılaşma baskısı altındadır. Yapılaşmanın biyolojik çeşitlilik üzerine en belirgin olumsuz etkisi de bitki türlerinin yetişme ve yaşama alanlarının daralması ve/veya yok olması şeklinde kendini göstermektedir. Araştırma alanında gerçekleştirilen farklı çalışmalarla bu etki, farklı yıllar için belirlenmiştir (Türkmen, 1987; Ünal, 1995; Göçük, 1996; Gövrek, 1997; Altunkasa ve ark., 1999). Ancak özellikle 2010 yll sonrasında yerleşke yapılaşma süreci geçmiş yıllara göre hız kazanmış ve yapılaşma alanı, yerleşkenin florası için oldukça önemli alanlar olan yerleşke güneydoğusuna doğru yönelmiştir. $\mathrm{Bu}$ durum da flora üzerinde önemli baskılara neden olmaktadır.

$\mathrm{Bu}$ çalışmanın amacı, Çukurova Üniversitesi Yerleşkesinde hızla artan yapılaşma sürecinin flora üzerindeki etkisini belirlemek ve biyolojik çeşitliliği korumaya yönelik çözüm önerileri geliştirmektir.

\section{MATERYAL ve METOT}

Araştırma alanını Çukurova Üniversitesi Yerleşkesi oluşturmaktadır. Çukurova Üniversitesi Yerleşkesi, Adana kenti kuzeyinde, Sarıçam ilçe sınırları içerisinde, Seyhan Barajı Gölü'nün doğusunda yer

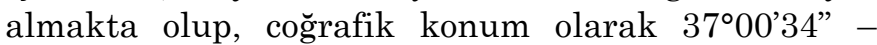
$37^{\circ} 05^{\prime} 00^{\prime \prime}$ kuzey enlemleri ile $35^{\circ} 20^{\prime} 15^{\prime \prime}-35^{\circ} 23^{\prime} 30^{\prime \prime}$ doğu boylamları arasındaki 1977.26 hektarlık bir 
alanı kapsamaktadır. Alanın kuzeyinde Menekşe Köyü, doğusunda Koza Arena Stadyumu (eski asfalt şantiyesi) ile Sofulu Mahallesi, güneyinde TEM-90 Otoyolu, Köprülü, Kışla, PTT Evleri Mahalleleri ve DSI kanalı, batısında Seyhan Baraj Gölü yer almaktadır (Şekil 1).

30.11.1973 tarihinde çıkan 1786 Sayılı Kanun ile 2 Fakülte olarak kurulan Çukurova Üniversitesi'nde, 2019 yılı Ocak ayı itibariyle 18 Fakülte, 4 Enstitü, 4 Yüksekokul, 12 Meslek Yüksekokulu, 1 Devlet Konservatuarı ile 25 Araştırma ve Uygulama Merkezi ile eğitim, araştırma ve bilimsel faaliyetler sürdürülmektedir.

Araştırmada yerleşkedeki artan yapılaşma sürecinin floraya olan etkisi, 5 aşamada belirlenmiştir.

Yerleşkede yapısal değişimin mevcut floraya etkisinin belirlenmesi ve günümüz floristik değişimin belirlenmesi için Çukurova Üniversitesi Yerleşkesi alanındaki ilk floristik çalışma olan Türkmen (1987) referans alınmıştır. Dolayısıyla araştırmada ilk olarak yerleşkenin 1987 yılı alan kullanımları ile günümüz (2018 yılı) alan kullanımları Googleearth uydu görüntüsü verileri kullanılarak, ArcGIS 10.0 bilgisayar yazılımı ile sınıflandırılmıştır.

Araştırmanın ikinci aşamasında, yerleşkenin günümüz florasının belirlenmesi için floristik arazi çalışmaları yapılmıştır.
Araştırma alanında eksiksiz bir floristik tarama yapabilmek için öncelikle alan, farklı habitat özellikleri gösteren Şekil 2'deki bölgelere ayrılmış ve bu bölgelere göre floristik arazi çalışmaları gerçekleştirilmiştir.

Floristik arazi çalışmaları, en az ayda bir kez olmak üzere, 2016-2018 yıllarını kapsayan 2 yıl boyunca yapılmıştır. Arazi çalışmaları sırasında mevcut bitki türleri yerinde fotoğraflanarak teşhis edilmiş, teşhis edilemeyenlerden örnek alınarak başta Flora of Turkey (Davis, 1965-1985) olmak üzere çeşitli flora ile ilgili kaynaklar (Güner ve ark., 2000; Güner ve ark., 2012) yardımıyla tanıları yapılmıştır. Alanda saptanan endemik ve nadir türlerin tehlike sinıfları ise Ekim ve ark. (2000), IUCN (2012), IUCN (2016)'ye göre belirlenmiştir. Bu aşamada ayrıca yerleşkede endemizm oranı da saptanmıştır.

Araştırmanın üçüncü aşamasında arazi çalışmaları kapsamında elde edilen veriler doğrultusunda bitkiler, öncelikle Raunkiaer'in hayat formlarına göre sınıflandırılmıştır (Raunkiaer, 1934). Daha sonra yerleşkenin antropojenik değişim derecesi saptanmıştır. Yerleşkenin antropojenik değişim derecesinin belirlenmesinde synantropizm indeksi kullanılmış olup, Eşitlik 1'e göre hesaplanmıştır (Jackowiak, 1990; Antipina, 2003; Kaminski, 2006).

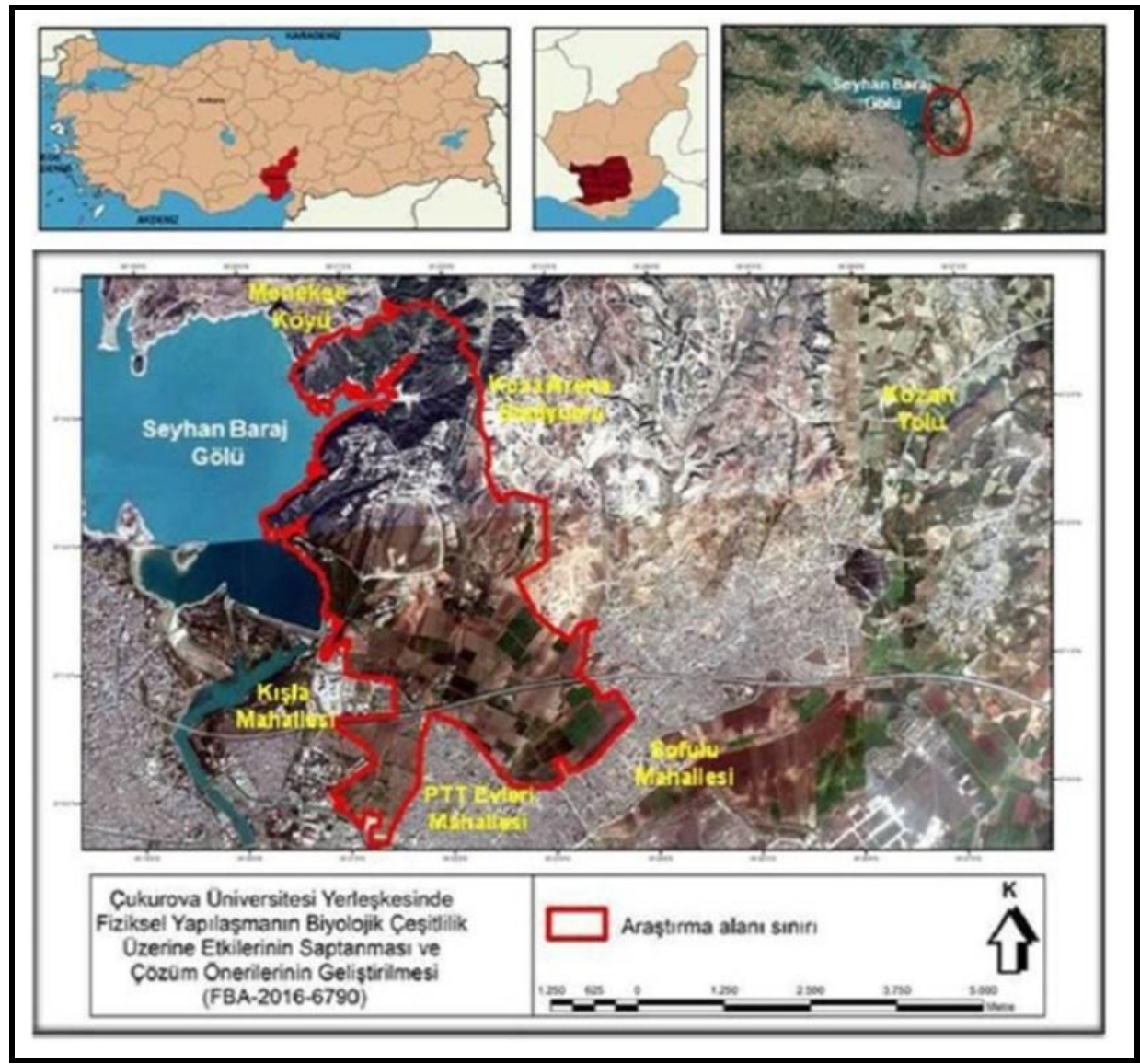

Şekil 1. Araştırma alanının konumu 


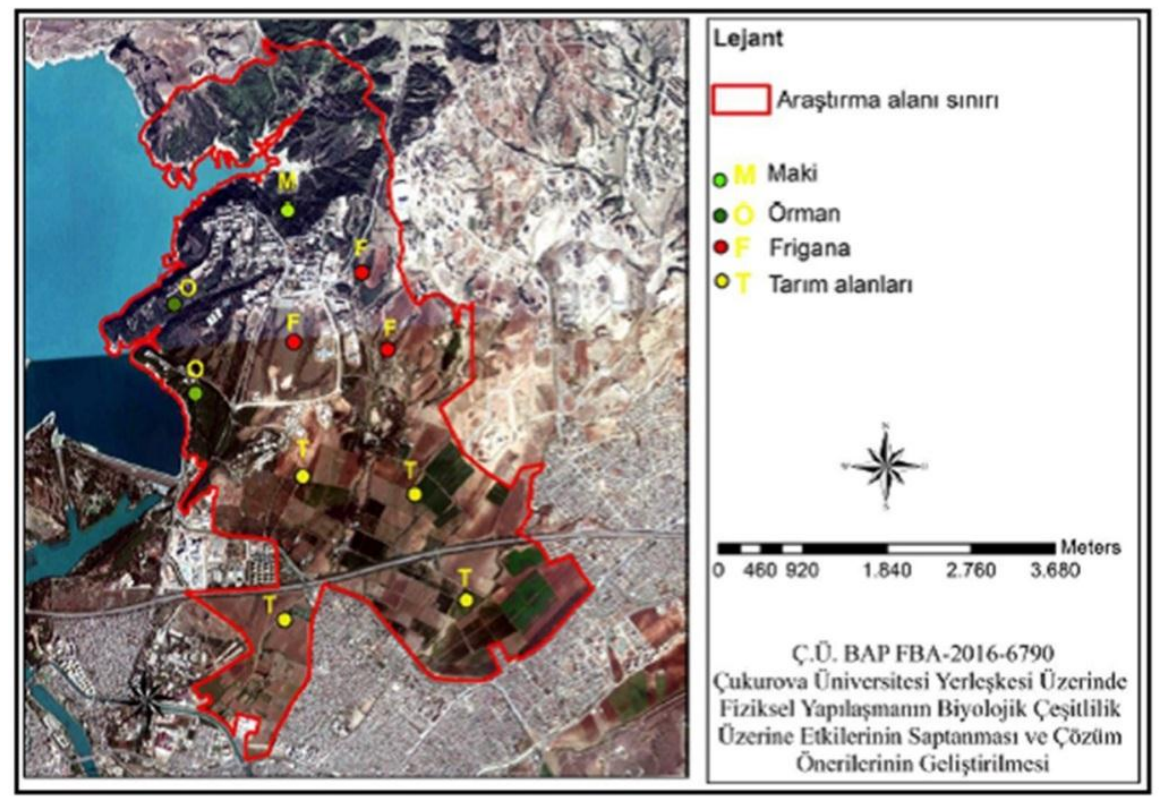

Şekil 2. Araştırma alanında floristik arazi çalışmaları için belirlenen bölgeler

Synantropizm İndeksi $=(\mathrm{Ap}+\mathrm{An}) /(\mathrm{Ap}+\mathrm{Sp}+\mathrm{An}) \mathrm{x}$ 100 (1)

Burada;

Apofitler (Ap) : Synantropik doğal türler (insanlar tarafindan oluşturulan alanlarda yayılan doğal bitkiler).

Spontanofitler (Sp): non-synantropik doğal türler (yayılmasinda insan etkisi olmayan türler)

Antropofitler: (An): alien (yabancı) türler (insanlar tarafindan oluşturulan alanlarda yayılan bölge için doğal olmayan bitkiler).

Yerleşkedeki bitki türlerinin önemli bir kısmı, bitkilendirme çalışmaları kapsamında oluşturulmuştur. Bu nedenle araştırmanın dördüncü aşamasında, bitkilendirme çalışmaları kapsamında kullanılan türler, doğal ve yabancı yurtlu olmak üzere iki sınıfta değerlendirilerek, tür bazında tespit edilmiştir.

Araştırmanın beşinci ve son aşamasında, yerleşkedeki tür değişimlerinin belirlenmesi amacıyla
Türkmen (1987)'in yerleşkede gerçekleştirdiği floristik arazi çalışması bulguları ile bu araştırma kapsamında gerçekleştirilen floristik arazi çalışma bulguları karşlaştırılmış ve yerleşkede 1987 yılına göre günümüzde kaybolan ve/veya yeni gelen türler belirlenmiştir. Böylece yerleşkedeki yapılaşma sürecinin flora üzerindeki etkisi belirlenerek, yapılaşma riski altındaki alanlar ArcGIS 10.0 bilgisayar yazılımı ile haritalanmış ve bu alanlar için öneriler geliştirilmiştir.

\section{BULGULAR}

Çukurova Üniversitesi Yerleşkesinin Alan Kullanım Değişimi

Araştırma alanının 1987-2018 yılları arasındaki zaman diliminde alan kullanımlarında önemli oranda bir değişim olduğu belirlenmiştir (Şekil 3). Bu değişim en belirgin olarak eğitim ve öğretim dokusu ile kara yolu ulaşım ağlarındaki artışta gözlemlenmiştir.
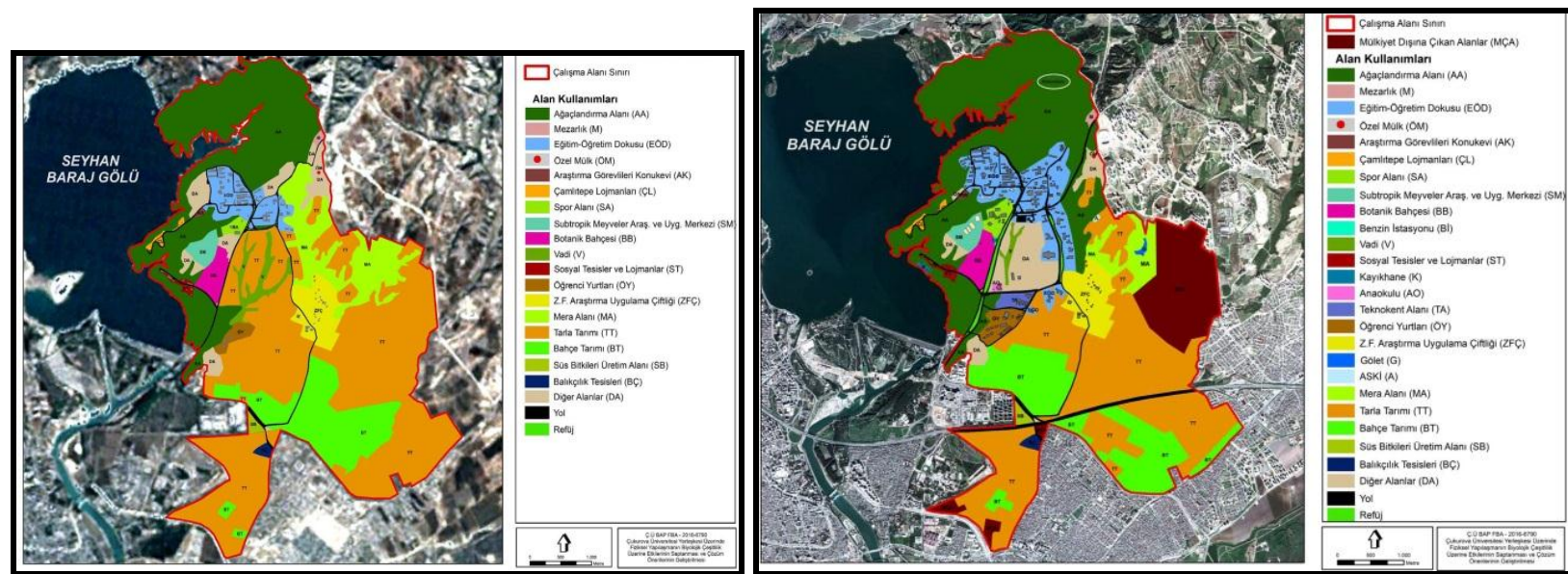

Şekil 3. Çukurova Üniversitesi Yerleşkesinin 1987 yılı (solda) ve 2018 yılı (sağda) alan kullanımları 
Yerleşkenin kurulduğu ilk dönemler olan 1980'li yıllarda araştırma alanının kuzeyinde yer alan eğitim öğretim dokusu, zaman içinde alanın güneydoğusuna doğru hızla ilerlemeye başlamıştır. Eğitim öğretim dokusu 1987 yllında 75.05 ha ile toplam alanin \% 3.50'sini oluştururken, 2018 yllında 148.74 ha ile alanın \% 6.90'nına ulaşmıştır. Yapılaşma nedeniyle alanın güneyinde bulunan tarım alanları ve zengin floraya sahip vadi alanları başta olmak üzere mera ve ağaçlandırma alanları da tahrip olmuştur.

Yapılaşma sürecine paralel olarak artan öğrenci ve personel sayısı nedeniyle de, hem mevcut karayolu ulaşım ağları genişletilmiş hem de yeni ulaşım ağları oluşturulmuştur. Karayolu ulaşım ağları, hem geçtiği güzergah boyunca habitatların yok olmassna hem de geçtiği alan içinde habitatların bölünmesine neden olarak yerleşkenin biyolojik çeşitliliğini olumsuz yönde etkilemiştir.

\section{Çukurova Üniversitesi Yerleşkesinin Florası}

$\mathrm{Bu}$ araştırma kapsamında gerçekleştirilen floristik arazi çalışmaları sonucunda yerleşke alanında 71 familya, 290 cins, 439 tür ve 454 doğal takson saptanmıştır (Çizelge 1).

Çizelge 1. Çukurova Üniversitesi Yerleşkesinde saptanan bitki familya cins, tür ve takson sayıları

\begin{tabular}{|c|c|c|c|c|}
\hline No & Familya & Cins (adet) & Tür (adet) & Takson (adet) \\
\hline 1 & AMARANTHACEAE & 1 & 2 & 2 \\
\hline 2 & ANACARDIACEAE & 3 & 5 & 5 \\
\hline 3 & APIACEAE & 13 & 17 & 17 \\
\hline 4 & APOCYNACEAE & 1 & 1 & 1 \\
\hline 5 & ARACEAE & 1 & 1 & 1 \\
\hline 6 & ARALIACEAE & 1 & 1 & 1 \\
\hline 7 & ASPARAGACEAE & 1 & 1 & 1 \\
\hline 8 & ASTERACEAE & 43 & 59 & 64 \\
\hline 9 & BORAGINACEAE & 9 & 10 & 10 \\
\hline 10 & BRASSICACEAE & 13 & 14 & 14 \\
\hline 11 & CAMPANULACEAE & 2 & 3 & 3 \\
\hline 12 & CAPPARACEAE & 1 & 1 & 1 \\
\hline 13 & CAPRIFOLIACEAE & 1 & 1 & 1 \\
\hline 14 & CARYOPHYLLACEAE & 7 & 10 & 11 \\
\hline 15 & CHENOPODIACEAE & 1 & 3 & 3 \\
\hline 16 & CISTACEAE & 3 & 8 & 8 \\
\hline 17 & CONVOLVULACEAE & 1 & 4 & 4 \\
\hline 18 & CUCURBITACEAE & 1 & 1 & 1 \\
\hline 19 & CUSCUTACEAE & 1 & 1 & 1 \\
\hline 20 & CYPERACEAE & 3 & 4 & 4 \\
\hline 21 & DIPSACACEAE & 2 & 2 & 2 \\
\hline 22 & EPHEDRACEAE & 1 & 1 & 1 \\
\hline 23 & EQUIESETACEAE & 1 & 1 & 1 \\
\hline 24 & ERICACEAE & 2 & 2 & 2 \\
\hline 25 & EUPHORBIACEAE & 4 & 9 & 9 \\
\hline 26 & FABACEAE & 25 & 66 & 67 \\
\hline 27 & FAGACEAE & 1 & 1 & 1 \\
\hline 28 & GENTIANACEAE & 2 & 2 & 2 \\
\hline 29 & GERANIACEAE & 2 & 6 & 7 \\
\hline 30 & HYPERICACEAE & 1 & 3 & 3 \\
\hline 31 & ILLECEBRACEAE & 1 & 1 & 1 \\
\hline 32 & IRIDACEAE & 4 & 5 & 5 \\
\hline 33 & JUNCACEAE & 1 & 1 & 1 \\
\hline 34 & LAMIACEAE & 15 & 17 & 17 \\
\hline 35 & LAURACEAE & 1 & 1 & 1 \\
\hline 36 & LILIACEAE & 13 & 22 & 22 \\
\hline 37 & LINACEAE & 1 & 2 & 2 \\
\hline 38 & MALVACEAE & 5 & 7 & 7 \\
\hline 39 & MORACEAE & 1 & 1 & 1 \\
\hline 40 & MYRTACEAE & 1 & 1 & 1 \\
\hline 41 & OLEACEAE & 4 & 4 & 5 \\
\hline 42 & ORCHIDACEAE & 3 & 4 & 4 \\
\hline
\end{tabular}




\begin{tabular}{|l|l|c|c|c|}
\hline 43 & OROBANCHACEAE & 1 & 1 & 1 \\
\hline 44 & OXALIDACEAE & 1 & 2 & 2 \\
\hline 45 & PAPAVERACEAE & 4 & 5 & 5 \\
\hline 46 & PINACEAE & 1 & 1 & 1 \\
\hline 47 & PLANTAGINACEAE & 2 & 6 & 1 \\
\hline 48 & PLUMBAGINACEAE & 1 & 1 & 52 \\
\hline 49 & POACEAE & 1 & 2 & 2 \\
\hline 50 & POLYGALACEAE & 2 & 3 & 3 \\
\hline 51 & POLYGONACEAE & 1 & 1 & 1 \\
\hline 53 & PORTULACACEAE & 2 & 2 & 3 \\
\hline 54 & RANUNCULACEAE & 6 & 12 & 14 \\
\hline 55 & RESEDACEAE & 1 & 1 & 1 \\
\hline 56 & RHAMNACEAE & 3 & 4 & 4 \\
\hline 57 & ROSACEAE & 5 & 5 & 5 \\
\hline 58 & RUBIACEAE & 5 & 8 & 1 \\
\hline 59 & RUTACEAE & 1 & 1 & 1 \\
\hline 60 & SANTALACEAE & 1 & 1 & 12 \\
\hline 61 & SCROPHULARIACEAE & 7 & 12 & 4 \\
\hline 62 & SOLANACEAE & 3 & 4 & 1 \\
\hline 63 & STYRACACEAE & 1 & 1 & 2 \\
\hline 64 & TAMARICACEAE & 1 & 1 & 1 \\
\hline 65 & THYMELAEACEAE & 2 & 2 & 1 \\
\hline 66 & TYPHACEAE & 1 & 1 & 3 \\
\hline 67 & URTICACEAE & 1 & 1 & 1 \\
\hline 68 & VALERIANACEAE & 1 & 3 & 454 \\
\hline 69 & VERBENACEAE & 3 & 1 & 139 \\
\hline 70 & VITACEAE & 1 & & 1 \\
\hline 71 & ZYGOPHYLLACEAE & & 1 & 1 \\
\hline Toplam & & 19 & 1 & \\
\hline & & & 1 & 1 \\
\hline
\end{tabular}

$\mathrm{Bu} 454$ taksondan 1 tanesi Pteridophyta (eğreltiler), 453 tanesi Spermatophyta (Tohumlu veya çiçekli bitkiler) bölümüne (division) aittir. $\mathrm{Bu}$ taksonlar içerisinde 2 tanesi Gymnospermae (Açıktohumlu), 452 tanesi Angiospermae (Kapalitohumlu) alt bölümüne dahildir. Angiospermae alt bölümüne dahil bitkilerden 91 tanesi Monokotiledon (Tekçenekli) sinıfında yer alırken, 363 tanesi Dikotiledon (Çiftçenekli) sınıfında yer almaktadır.

\section{Yerleşkedeki Taksonların Hayat Formlarına Göre Sinuflandirılması}

Araştırma alanında tespit edilen taksonların Raunkiaer'in hayat formlarına göre sınıflaması, Şekil 4'de belirtilmiştir.

Şekil 4'de belirtildiği gibi, hayat formaları açısından Yerleşkedeki taksonların yarısı terofitlerden, \% 22'si hemikriptofitlerden, \% 10'u ise geofitlerden oluşmaktadır. Yerleşkede hayat formları açısından en az bulunan takson ise \% 5 ile kamefitlerdir.

Hayat formlarına göre araştırma alanında bulunan türlerin \% 13'ü odunsu karakterde, geri kalanının ise otsu karakterde olduğu tespit edilmiştir.

\section{Yerleşkedeki Endemik Bitkiler}

Yerleşkede endemizm oranı ise \% 4.4 bulunmuş olup, yerleşke alanındaki toplam 21 taksonun Türkiye için endemik olduğu saptanmıştır. Bu taksonlar Çizelge 2'de tehlike sınıfları ile verilmiştir.

Endemik türlerin habitatları incelendiğinde \%19'unun (4 takson) daha korunaklı sayılabilecek maki ve orman alanlarında yaşadığı, \% 42 'sinin (9 takson) frigana, \% 38'inin (8 takson) terkedilmiş tarım alanlarında yer aldığı belirlenmiştir. Buna göre büyük çoğunluğunun yaşadığı alanlar, alan kullanımlarının değişmesi tehdidi ile karşı karşıyadır. Yerleşkedeki endemik türlerden IUCN tehlike sinuflarina göre 4 tür VU (VulnerableDuyarlı), 4 tür CR (Critically Endangered-Kritik), 7 tür LC (Least Concern-Düşük riskli) ve 6 tür de NT (Near Threatened-Tehdite yakın) tehlike sinıflarına girmektedir.

\section{Yerleşke Alanında Antropojenik Değişim Derecesi}

Araştırmanın bu bölümünde türlerin antropojenik değişim derecesi, synantropizasyon indeksinin hesaplanması ile belirlenmiştir. Floristik arazi çalışmaları ve yapılan önceki çalışmalar doğrultusunda, araştırma alanındaki bitki türleri Apofitler, Spontanofitler ve Antropofitler olarak sınıflandırılmıştır (Çizelge 3 ve Şekil 5).

Yerleşkedeki bitki türlerinin \% 25’i apofitlerden, \% 9 'u antropofitlerden ve \% 66 'sı da spontanofitlerden 
oluşmaktadır. Şekil 5'deki veriler kullanılarak, araştırma alanının antropojenik değişim derecesi hesaplanmış ve \% 33.5 bulunmuştur.

Yerleşkede Bitkilendirme Çalışmaları ve Kullanılan Türler

Yerleşkedeki bitkilendirme çalışmaları kuruluş yıllarından itibaren sürdürülmektedir. Kuruluş yıllarında çam türleri (Pinus sp.), servi türleri (Cupressus sp.), yalanc1 akasya (Robinia pseudoacacia) ve okaliptüs (Eucalyptus camaldulensis) başta olmak üzere çeşitli türlerle bitkilendirmeler yapılmıştır.

Çizelge 2. Yerleşke alanı endemik bitkileri, tehlike sınıfları, hayat formları ve habitatları IUCN (2012, IUCN, 2016)

\begin{tabular}{|c|c|c|c|c|c|}
\hline No & Adı & Türkçe adı & $\begin{array}{l}\text { IUCN tehlike } \\
\text { sinif:* }\end{array}$ & Hayat Formu & Habitat \\
\hline \multicolumn{6}{|c|}{ APIACEAE } \\
\hline 1 & Bupleurum polyactis Post ex Snogerup & Koca şeytanayağı & VU & Terofit & Maki \\
\hline \multicolumn{6}{|c|}{ ASTERACEAE } \\
\hline 2 & $\begin{array}{l}\text { Centaurea calcitrapa L. subsp. cilicica } \\
\text { (Boiss. et Bal.) Wagenitz }\end{array}$ & Çobanziplatan & CD & Terofit & $\begin{array}{l}\text { Terkedilmiş } \\
\text { Tarım Alanları }\end{array}$ \\
\hline 3 & Centaurea haradjianii Wagenitz & Kaputkulak & VU & Hemikriptofit & $\begin{array}{l}\text { Terkedilmiş } \\
\text { Tarım Alanları }\end{array}$ \\
\hline 4 & $\begin{array}{l}\text { Centaurea solstitialis L. subsp. carneola } \\
\text { (Boiss.) Wagenitz }\end{array}$ & $\mathrm{Al}$ kababaş & NT & Terofit & $\begin{array}{l}\text { Terkedilmiş } \\
\text { Tarım Alanları }\end{array}$ \\
\hline 5 & $\begin{array}{l}\text { Centaurea solstitialis L. subsp. pyracantha } \\
\text { (Boiss.) Wagenitz }\end{array}$ & Kababaş dikeni & NT & Terofit & $\begin{array}{l}\text { Terkedilmiş } \\
\text { Tarım Alanları }\end{array}$ \\
\hline 6 & Onopordum boisseri Willk. & Kahve dikeni & NT & Hemikriptofit & Frigana \\
\hline \multicolumn{6}{|c|}{ FABACEAE } \\
\hline 7 & Onobrychis tournefortii (Willd.) Desv. & Evliya otu & $\mathrm{LC}$ & Hemikriptofit & Frigana \\
\hline 8 & Trifolium aintabense Boiss. et Hausskn. & Antep tırfilı & NT & Terofit & $\begin{array}{l}\text { Terkedilmiş } \\
\text { Tarım Alanları }\end{array}$ \\
\hline 9 & Trigonella kotschyi Fenzl & Ak boyotu & $\mathrm{LC}$ & Terofit & $\begin{array}{l}\text { Terkedilmiş } \\
\text { Tarım Alanları }\end{array}$ \\
\hline \multicolumn{6}{|c|}{ HYPERICACEAE GUTTIFARAE } \\
\hline 10 & $\begin{array}{l}\text { Hypericum polyphyllum Boiss. et Bal. } \\
\text { subsp. polyphyllum Boiss. et Bal. }\end{array}$ & Hoş kantaron & NT & Hemikriptofit & Frigana \\
\hline \multicolumn{6}{|c|}{ LAMIACEAE } \\
\hline 11 & $\begin{array}{l}\text { Stachys annua (L) L. subsp. cilicica (Boiss.) } \\
\text { Bhattacharjee }\end{array}$ & Dağ çayçesi & $\mathrm{LC}$ & Terofit & $\begin{array}{l}\text { Ormanlık } \\
\text { Alanlar }\end{array}$ \\
\hline 12 & $\begin{array}{l}\text { Stachys sparsipilosa Bhattacharjee et Hub.- } \\
\text { Mor. }\end{array}$ & Seyrek deliçay & $\mathrm{LC}$ & Hemikriptofit & $\begin{array}{l}\text { Terkedilmiş } \\
\text { Tarım Alanları }\end{array}$ \\
\hline 13 & Thymus cilicicus Boiss. et Bal. & Kılçık kekiği & LC & Kamefit & Frigana \\
\hline \multicolumn{6}{|c|}{ LILIACEAE } \\
\hline 14 & Allium gayi Boiss. & Küçük soğan & NT & Geofit & Frigana \\
\hline 15 & Bellevalia modesta Wendelbo & Tarla sümbülü & CD & Geofit & Frigana \\
\hline 16 & $\begin{array}{l}\text { Hyacinthella glabrescens (Boiss.) K. } \\
\text { Persson et Wendelbo }\end{array}$ & Köse sümbül & $\mathrm{CD}$ & Geofit & Frigana \\
\hline 17 & Hyacinthella heldreichii (Boiss.) Chouard & Gece sümbülü & $\mathrm{LC}$ & Geofit & Frigana \\
\hline 18 & Hyacinthella hispida (J. Gay) Chouard & Kıllı sümbül & VU & Geofit & $\begin{array}{l}\text { Terkedilmiş } \\
\text { Tarım Alanları }\end{array}$ \\
\hline & Muscari muscarimi Medikus & Müşkürüm & $\mathrm{VU}$ & Geofit & Frigana \\
\hline \multicolumn{6}{|c|}{ RHAMNACEAE } \\
\hline & Rhamnus hirtellus Boiss. & Has cehri & $\mathrm{LC}$ & Fanerofit & Maki \\
\hline \multicolumn{6}{|c|}{ SCROPHULARIACEAE } \\
\hline 21 & Scrophularia trichopoda Boiss. et Bal. & Üç sıraca & $\mathrm{CD}$ & Hemikriptofit & Maki \\
\hline
\end{tabular}

* VU-Duyarlı, CD-Korumaya tabi, LC-Düşük riskli, NT-Tehdite yakın

Çizelge 3. Türlerin antropojenik değişim indeksi değerlerinin açıklaması

\section{Antropojenik Dönüşüm Sınıfi Apofitler (Ap)}

Spontanofitler (Sp)

Antropofitler (An)

\section{Açıklaması}

Synantropik doğal türler (insanlar tarafından oluşturulan alanlarda yayılmacı doğal türler/antropofilik türler).

Non-synantropik doğal türler (doğal alanlara özgü insan aktivitelerinden olumsuz etkilenen türler/antropofobik türler).

Alien yani alanda önceden olmayan yabancı türler (araştırma alanına sonradan katılan antropofilik/synantropik ve non-synantropik/antropofobik türler). 


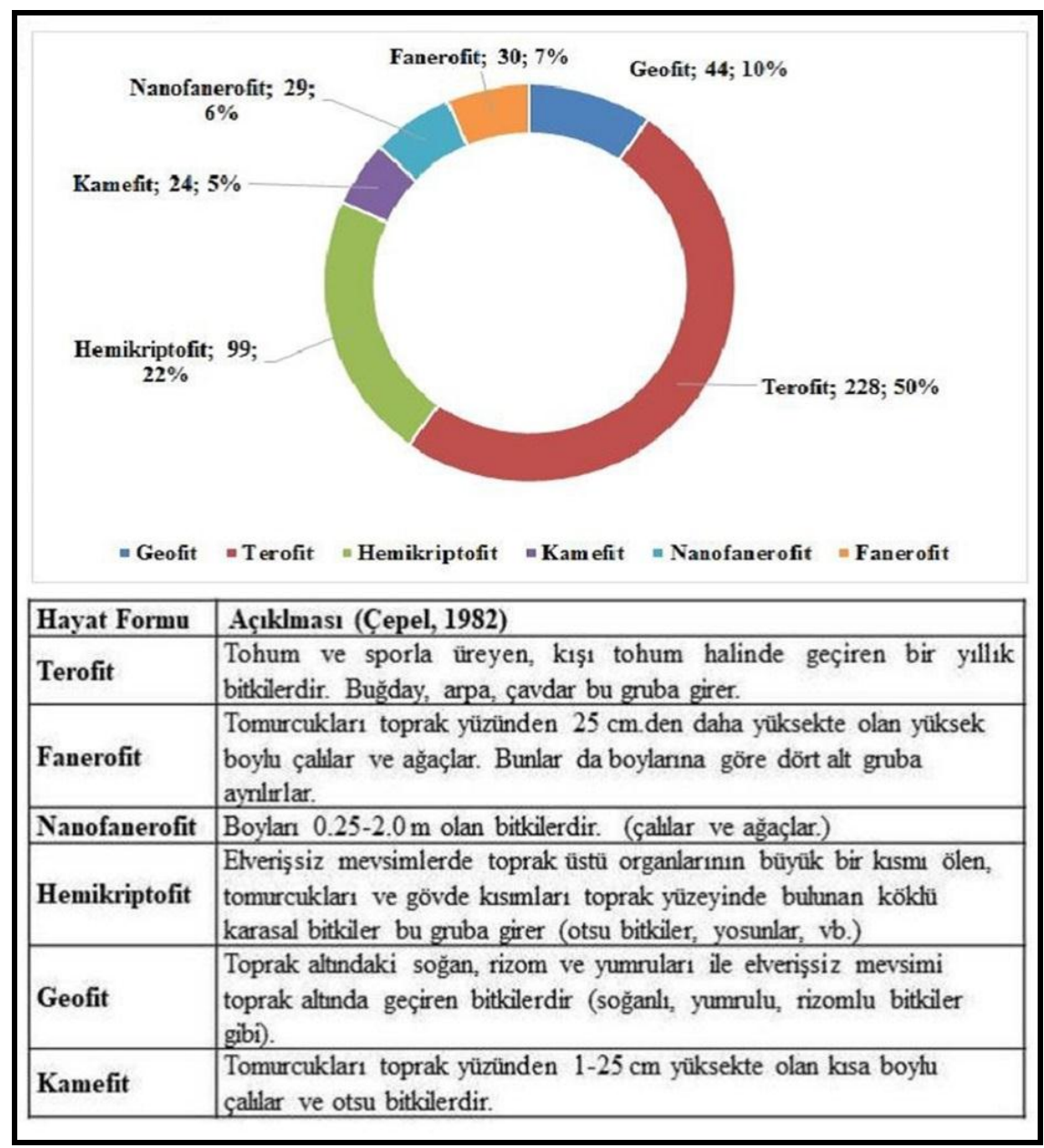

Şekil 4. Taksonların hayat formları ve yüzdelik dilimleri

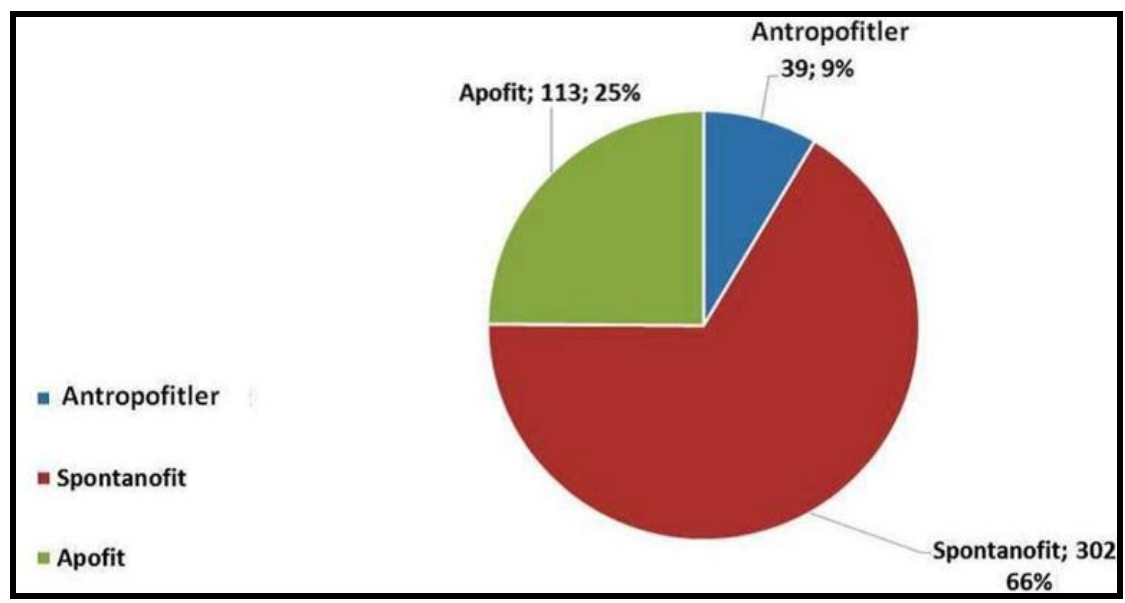

Şekil 5. Türlerin antropojenik değişim indeksi değerlerine dağılımları

Ancak, bu konuda belirli bir plan çerçevesinde yapılmış projeler bulunmamaktadır. Yeni yapılan bazı birimlerin çevreleri için bazı peyzaj projeleri üretilmekle birlikte, bunlar yerleşke geneli ile oranlandığında küçük parçalar halinde kalmaktadır. Aynı zamanda bu projelerin uygulanmasinda da genelde sert zemin tasarımlarına ağırlık verilmekte, bitkisel tasarımda ise projelere daha az uyum sağlanmaktadır.

Araştırma alanında bitkilendirme çalışmaları kapsamında 181 adet tür saptanmış olup, bu türlerden 138 adedi yabancı yurtlu türlerden, sadece 43 adedi ise doğal bitki örtüsüne ait olan türlerden oluşmaktadır (Çizelge 4).

Yerleşke genelinde bitkilendirme çalışmaları kapsamında yabancı yurtlu türlerin kullanımı yoğundur. Kent genelinde kullanım yoğunluğu fazla olan türler yerleşke genelinde de yoğun kullanılmıştır. Örneğin kent genelinde yollar boyunca kullanılan palmiyelere yerleşkedeki yollarda da 
rastlanmaktadır. Son zamanda yapılan düzenleme ile yerleşkeye giriş-çıkış yolu boyunca neredeyse $1 \mathrm{~m}$ arayla palmiyeler dikilmiştir. Ayrıca yerleşke içindeki tüm alanlara gereğinden sık düzende çok sayıda Ficus microcarpa türünün bireyleri dikilmektedir. Yabancı yurtlu ve tropik bölgelere ait olan bu türü düşük sıcaklıklardan korumak amacıyla da çeşitli önlemler alınmaktadır.

\section{TARTIŞMA ve SONUÇ}

Çukurova Üniversitesi Yerleşkesi bulunduğu bölge Akdeniz havzası içinde önemli bir koridor üzerinde yer almaktadır (Critical Ecosystem, 2017). Dolayısıla tüm Akdeniz havzasında Çukurova Üniversitesi Yerleşkesinin de içinde bulunduğu bölge, Türe ve Böcük (2010)'ün de belirttiği gibi yüksek koruma gereksinimi olan bölgeler arasındadır.

Yerleşke alanında bulunan bitki türlerinin Akdeniz Havzası, Türkiye ve Adana ili ölçeğindeki çeşitlilik durumu incelendiğinde, Türkiye'deki bitkilerin \% 10.7'sini barındıran Adana İlinin toplam doğal taksonlarının \% 32.3'ünün Çukurova Üniversitesi Yerleşkesinde temsil edildiği anlaşılmaktadır (Çizelge5)

Dolayısıyla araştırma alanı olan Çukurova Üniversitesi Yerleşkesi, Darıcı ve ark. (2016)'nın da belirttikleri gibi dünyanın pek çok ülkesini temsil eden ağaç ve çalıları barındırması ve bir botanik bahçesi kadar zengin olması nedenleriyle, bitki türlerinin ve bu türlerin yaşam alanlarının korunmasında oldukça önemli bir alandır. Ancak Yerleşkenin eğitim öğretim dokusu ve ulaşım gibi yapılaşma süreci de devam etmektedir. Yerleşke yapılaşma sürecinin flora üzerindeki etkisini belirlemek amacıyla, yerleşke sınırlarında flora konusunda yapılan ilk çalışma olan Türkmen (1987) referans alınarak, bu araştırma kapsamında yapılan floristik arazi çalışma bulguları ile karşılaştırılmıştır. Karşılaştırma sonucunda yerleşke florasındaki değişimler tespit edilmiş ve familya, cins, tür ve alt tür düzeyindeki değişiklikler Çizelge 6'da belirtilmiştir.

Çizelge 6. Floristik bulguların kıyaslanması

\begin{tabular}{lll} 
& Türkmen (1987) & Floristik arazi çalışması bulguları (2017-2018) \\
\hline Familya sayısı & 67 & 71 \\
\hline Cins sayısı & 265 & 290 \\
\hline Tür ve tür altı takson sayısı & 415 & 454 \\
\hline
\end{tabular}

$\mathrm{Bu}$ araştırmanın floristik bulguları değerlendirildiğinde, yerleşkenin 30 yıllık değişim süreci kapsamında Türkmen (1987) bulgularına göre yerleşke florasında takson kaybı olmadığı, yerleşke florasına 4 yeni familya, 25 cinse ait 39 tür veya tür altı takson eklendiği tespit edilmiştir. Bunların 18 tanesi (Arum dioscorides, Bidens bipinnata, Carduus pycnocephalus subsp. albidus, Chrysanthemum segetum, Taraxacum hellenicum, Nonea ventricosa, Hirschfeldia incana, Ochtodium aegyptiacum, Vaccaria pyramidata, Stellaria media, Medicago sativa, Trifolium pratense, Geranium molle, Ficus carica, Oxalis pes-caprae, Veronica polita, Anagallis arvensis var. arvensis, Adonis microcarpa) synantropik doğal taksonlar, geriye kalan 21 tanesi ise non-synantropik doğal taksonlardır (Çizelge 7).

Söz konusu alanda takson sayısı artışının nedenlerinin başında, alanın dışarıdan gelen kentsel yapılaşma baskısından korunması gelmektedir.

$\mathrm{Bu}$ araştırma sonuçları ile kayda geçen yeni taksonlarla yerleşkenin tür ve tür altı takson sayısı 454 , cins sayısı 290 ve familya sayısının 71 olduğu belirlenmiştir. Ayrıca, yerleşke alanında endemizm oranının \% 4.4 olduğu belirlenerek, toplam 21 taksonun Türkiye için endemik olduğu saptanmıştır. Cizelge 7'de belirtilen yeni eklenen taksonlar, hayat formlarına göre sınıflandırılmış ve Türkmen (1987)'in gerçekleştirdiği araştırma bulguları ile karşılaştırılarak Çizelge 8'de taksonların hayat formlarına göre değişimleri tespit edilmiştir. Yeni eklenen taksonların özellikle terofit formunda artış olduğu gözlenmiştir. Yerleşkenin terofitler olarak oldukça zengin bir alan olduğu saptanmıştır.

Yerleşkeye yeni eklenen taksonların habitat dağılımları (Şekil 6) değerlendirildiğinde ise, özellikle yerleşkedeki terkedilmiş tarım alanlarının ve friganaların yerleşkeye yeni eklenen taksonlar için önemli alanlar olduğu belirlenmiştir.

Yeni eklenen taksonlarla birlikte tüm yerleşke florasındaki taksonlar değerlendirildiğinde ise, en fazla takson içeren Fabaceae familyasının \% 23.9'u (16 takson) maki, \% 55.2'si (37 takson) terkedilmiş tarım alanları, \% 9 (6 takson) frigana, \% 11.9 (8 takson) nemli yerlerde yer aldığı saptanmıştır.

$\mathrm{Bu}$ familya üyelerinden sadece \% 23.9'u daha korunaklı alanlar olarak kabul edilebilecek maki formasyonu içinde yaşam alanı bulmuştur. Diğer taksonlar ise özellikle yeni yapılaşmaların olduğu terkedilmiş tarım alanları, frigana ve nemli alanlarda yaşamaktadır. Benzer şekilde Asteraceae familyasinın sadece \% 15.6'sı (10 takson) daha korunaklı sayılabilecek maki içinde, Poaceae familyası üyelerinin \% 21.1'i (11 takson) maki ve orman alanlarında, Liliaceae familyasının \% 27.27'si (6 takson) de yine daha korunaklı sayılabilecek maki ve orman alanlarında yaşamaktadır. 
Çizelge 7. Yerleşke florasında yeni kayda geçen taksonlar (koyu renkli olanlar synantropik, diğerleri nonsynantropik taksonlardır)

\begin{tabular}{|c|c|c|c|}
\hline Sira & Familyası & Adı & Habitatı \\
\hline 1 & Araceae & Arum dioscorides SM. & Frigana \\
\hline 2 & Araliaceae & Hedera helix L. & Maki \\
\hline 3 & Asparagaceae & Ruscus aculeatus L. & Maki \\
\hline 4 & \multirow[t]{5}{*}{ Asteraceae } & Bidens bipinnata $L$. & Frigana \\
\hline 5 & & $\begin{array}{l}\text { Carduus pycnocephalus L. subsp. albidus } \\
\text { (BIEB.) KAZMI }\end{array}$ & Terkedilmiş Tarım Alanları \\
\hline 6 & & Chrysanthemum segetum $L$. & Terkedilmiş Tarım Alanları \\
\hline 7 & & Inula viscosa (L.) AITON & Frigana \\
\hline 8 & & Taraxacum hellenicum DAHLST & Terkedilmiş Tarım Alanları \\
\hline 9 & Boraginaceae & Nonea ventricosa (SM.) GRISEB. & Terkedilmiş Tarım Alanları \\
\hline 10 & \multirow[t]{3}{*}{ Brassicaceae } & Hirschfeldia incana (L.) LAG.-FOSS & Terkedilmiş Tarım Alanları \\
\hline 11 & & Ochtodium aegyptiacum $L$ & Terkedilmiş Tarım Alanları \\
\hline 12 & & Vaccaria pyramidata MEDIK. & Terkedilmiş Tarım Alanları \\
\hline 13 & Caryophyllaceae & Stellaria media (L.) Vill. & Frigana \\
\hline 14 & Cistaceae & Fumana arabica $L$. & Frigana \\
\hline 15 & Ericaceae & Arbutus andrachne $L$. & Maki \\
\hline 16 & \multirow{4}{*}{ Fabaceae } & Cercis siliquastrum $L$. & Maki \\
\hline 17 & & Medicago sativa $L$. & Terkedilmiş Tarım Alanları \\
\hline 18 & & $\begin{array}{l}\text { Pisum sativum L. subsp. sativum L. var. } \\
\text { arvense POIRET }\end{array}$ & Terkedilmiş Tarım Alanları \\
\hline 19 & & Trifolium pratense $L$ & Terkedilmiş Tarım Alanları \\
\hline 20 & Geraniaceae & Geranium molle L. & Terkedilmiş Tarım Alanları \\
\hline 21 & \multirow[t]{5}{*}{ Liliaceae } & $\begin{array}{lll}\text { Hyacinthella glabrescens } & \text { (BOISS.) K. } \\
\text { PERSSON ET WEND. } & & \\
\end{array}$ & Frigana \\
\hline 22 & & $\begin{array}{l}\text { Hyacinthella heldreichii } \\
\text { CHOUARD }\end{array}$ & Frigana \\
\hline 23 & & Hyacinthella hispida (J. GAY) CHOUARD & Terkedilmiş Tarım Alanları \\
\hline 24 & & Muscari tenuiflorum TAUSCH & Frigana \\
\hline 25 & & Smilax excelsa $L$ & Frigana \\
\hline 26 & Moraceae & Ficus carica $L$. & Frigana \\
\hline 27 & \multirow[t]{2}{*}{ Orchidaceae } & Ophrys umbilicata DESF. & Frigana \\
\hline 28 & & Orchis italica POIRET & Frigana \\
\hline 29 & Oxalidaceae & Oxalis pes-caprae L. & Terkedilmiş Tarım Alanları \\
\hline 30 & Plantaginaceae & Misopates orontium (L.) RAFIN. & Frigana \\
\hline 31 & Poaceae & $\begin{array}{l}\text { Phragmites australis (CAV.) TRIN. EX } \\
\text { STEUDEL }\end{array}$ & Nemli yerler \\
\hline 32 & Primulaceae & Anagallis arvensis L. var. arvensis L. & Terkedilmiş Tarım Alanları \\
\hline 33 & \multirow[t]{2}{*}{ Ranunculaceae } & Adonis microcarpa $D C$. & Terkedilmiş Tarım Alanları \\
\hline 34 & & Clematis vitalba $L$. & Frigana \\
\hline 35 & Rhamnaceae & Rhamnus oleoides L. & Maki \\
\hline 36 & Rosaceae & Rosa canina $L$ & Maki \\
\hline 37 & Rubiaceae & Putoria calabrica (L. FIL.) DC. & Terkedilmiş Tarım Alanları \\
\hline 38 & \multirow[t]{2}{*}{ Scrophulariaceae } & Anarrhinum orientale BENTHAM & Frigana \\
\hline 39 & & Veronica polita FRIES & Terkedilmiş Tarım Alanları \\
\hline
\end{tabular}

Çizelge 8. Hayat formlarındaki değişimin kıyaslanması

\begin{tabular}{llllllll}
\hline & Geofit & Terofit & Hemikriptofit & Kamefit & Nanofanerofit & Fanerofit & Toplam \\
\hline Yeni Veriler & 43 & 229 & 99 & 24 & 29 & 30 & 454 \\
\hline Türkmen (1987) & 35 & 211 & 98 & 21 & 28 & 22 & 415 \\
\hline Değişim & 8 & 18 & 1 & 3 & 1 & 8 & 39 \\
\hline
\end{tabular}




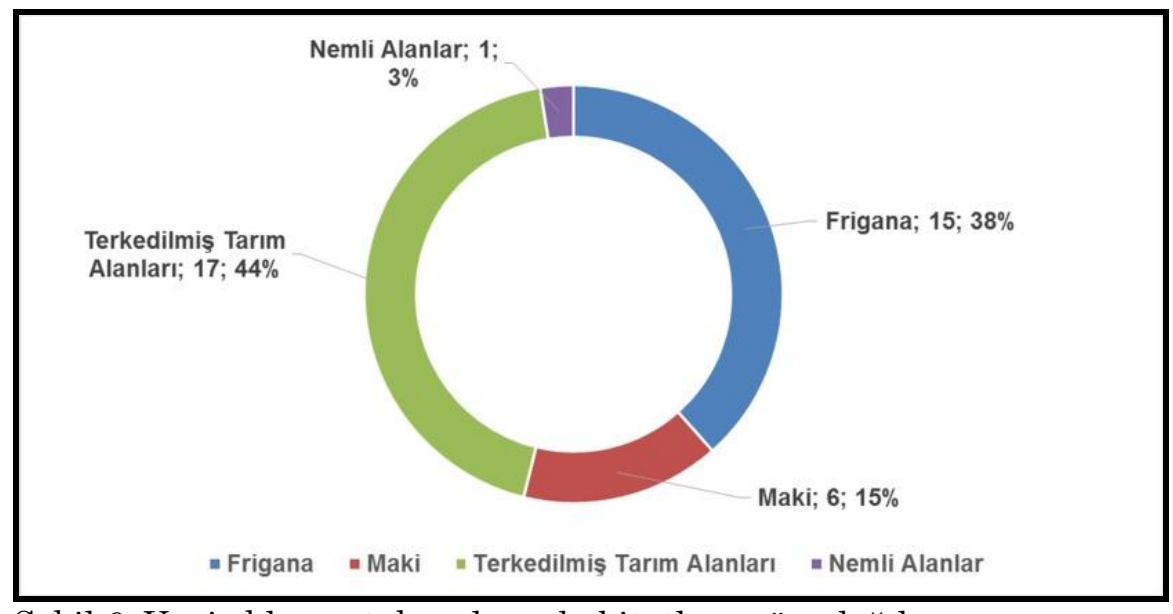

Şekil 6. Yeni eklenen taksonların habitatlara göre dağılımı

Endemik türlerin yaşam alanları incelendiğinde ise \% 19'unun (4 takson) daha korunakl sayılabilecek maki ve orman alanlarında yaşadığı, \% 42'sinin (9 takson) frigana, \% 38'inin (8 takson) terkedilmiş tarım alanlarında yaşadığı belirlenmiştir. Yerleşkedeki endemik türlerden IUCN tehlike sinıflarına göre VU sinıfındaki 4 tür ve CR sınıfındaki 4 tür makilik alanlarda, terkedilmiş tarım alanları ve friganada; NT sinıfındaki 6 tür ise frigana ve tarım alanlarında yer almaktadır. Dolayısıyla IUCN kategorilerine göre endemik türler için frigana, maki ve terkedilmiş tarım alanları oldukça önemli yaşam alanlarıdır.

Yerleşkenin coğrafi özellikler bakımından zengin olması, bir bölümünün korunan alan sinırları içerisinde olması (Şekil 7) ve alanın kamu alanı olmasından dolayı kent kaynaklı yapılaşma baskısından korunması, yerleşkedeki flora zenginliğinin önemli nedenleri arasındadır. Ayrıca yerleşkedeki artan eğitim öğretim dokusu kaynaklı yapılaşma süreci her ne kadar doğal yapı üzerinde olumsuz etkilere neden olsa da, söz konusu yapılaşan alanlar çevresinde yapılan bitkilendirme çalışmaları da florada artan takson sayısının nedenleri arasinda yer almaktadır. Ancak söz konusu bitkilendirme çalışmaları yerleşke genelinde yapılan bir planlama kapsamında oluşturulmamakta, yeni yapılaşan alanlar çevresinde projelerle oluşturulmaktadır. Bu durum da yerleşkedeki yeşil alanlardan beklenen fonksiyonların elde edilememesine sadece yeşil alan miktarının arttırılmasına katkı sağlamaktadır. Oysa Çukurova Üniversitesi Yerleşkesi sadece kendi içinde değil, Adana genelinde de yaşamsal önemde bir yeşil alan niteliğindedir. Dolayısıyla Yerleşke genelinde belirli bir plan dâhilinde, doğal yapıyı koruyacak ve geliştirecek, yeşil alanlardan beklenen fonksiyonları yerine getirebilecek bir bitkilendirme yapılması ve bakım uygulamalarıyla da bu alanların sürdürülebilirliğinin sağlanması gerekmektedir. $\mathrm{Bu}$ kapsamda yerleşke geneli için yapılacak genel bitkilendirme esasları, sınıflandırılmış alanlara uygun olarak ele alınmalıdır. Genel olarak eğitim dokusu içinde kullanıcıların konforuna ve eğitimlerine; ayrıca bölgenin doğal yapısına destek veren bir anlayışla bitkilendirme çalışmaları yapılmalıdır. $\mathrm{Bu}$ kapsamda Yerleşke alanı için hazırlanacak bir plan-proje dâhilinde bitkilendirme çalışmalarının yeniden ele alınması ve bakımyönetim işinin kurumsallaşarak, bitkilendirme ve bakım çalışmalarına belirli bir bütçenin ayrılması gerekmektedir.

Sonuç olarak, yerleşke alanındaki mevcut doğal flora, 30 yıl öncesindeki doğal floraya göre hem synantropik, hem de non-synantropik doğal türlerin yerleşmesiyle 415 taksondan 454 taksona artmıştır. Sayısal olarak gerçekleşen bu artış, florada belirgin bir değişime neden olmuştur. Yerleşkenin 30 yl önceki florasının synantropik dönüşüm derecesi Türkmen (1987) tarafından \% 27.2 olarak belirlenmişken; bu araştırma ile günümüzdeki synantropik dönüşüm derecesi \% 33.5 olarak saptanmıştır. $\mathrm{Bu}$ değerler, yerleşke florasının synantropik değişim derecesinin gittikçe arttığını göstermektedir. Bu değişimin olumlu yönde mi yoksa olumsuz yönde mi sonuçlanacağı, ilerleyen yıllarda bu araştırmaya benzer çalışmaların yapılmasıyla daha somut olarak görülecektir. Ancak söz konusu süreç kapsamında yerleşkedeki yapılaşma sürecinin flora üzerinde yaptığı olumsuz etkiler Şekil 7'de açıkça görülmektedir. Floradaki takson sayısı her ne kadar artış göstermiş olsa da, yerleşkedeki yapılaşma süreci, taksonların yaşam alanlarına hem doğrudan, hem de dolaylı olarak zarar vermektedir. Özellikle yerleşkedeki yeni eğitim öğretim dokusu ile Teknokent alanları ve bu alanlara ulaşımı sağlayan karayolu ağlarının çoğunluğu flora için riskli alanlarda yapılandırılmaktadır. Ayrıca endemik taksonların büyük çoğunluğunun yaşadığı alanlar, alan kullanımlarının değişmesi tehdidi ile karşı karşıyadır (Şekil 7).

Şekil 7'de de görüldüğü gibi yerleşkenin kuzey ve batı kısmı yaban hayatı geliştirme sahası içerisinde yer almaktadır ve dolayısıyla da bu alanda yapisal alan 
dışındaki yerler maki ve ormanlık alanlarla örtülü durumdadır. Böylece bu alanlardaki flora, yerleşkenin diğer alanlarındaki floraya göre kısmen de olsa daha iyi korunmuştur.

Yaban hayatı geliştirme sahası sınırları dışında kalan alanlarda ise makinin tahribi ile oluşan frigana yer almaktadır. Şekil 7'deki 1 nolu alan flora çalışmaları için temel alınan 1987 yılında frigana olup, floranın zengin olduğu vadiler ve vadiler dışında ise tarım yapılan alanlardır. Flora için oldukça önemli olan bu frigana alanı günümüzde (Şekil 7'deki 4 nolu alan) Teknokent, anaokulu, kongre merkezi gibi yapılaşma baskısı altında kalmıştır. Ayrıca yine 1987 yılında tarım ve mera alanı olarak kullanılan SSekil 7'deki 2 nolu frigana örtülü alan, günümüzde (Şekil 7'deki 5 nolu alan) yeni eğitim öğretim dokusu ve karayolu ulaşım ağı ile yapılaşmış ve flora geri dönülemez şekilde tahrip olmuştur.
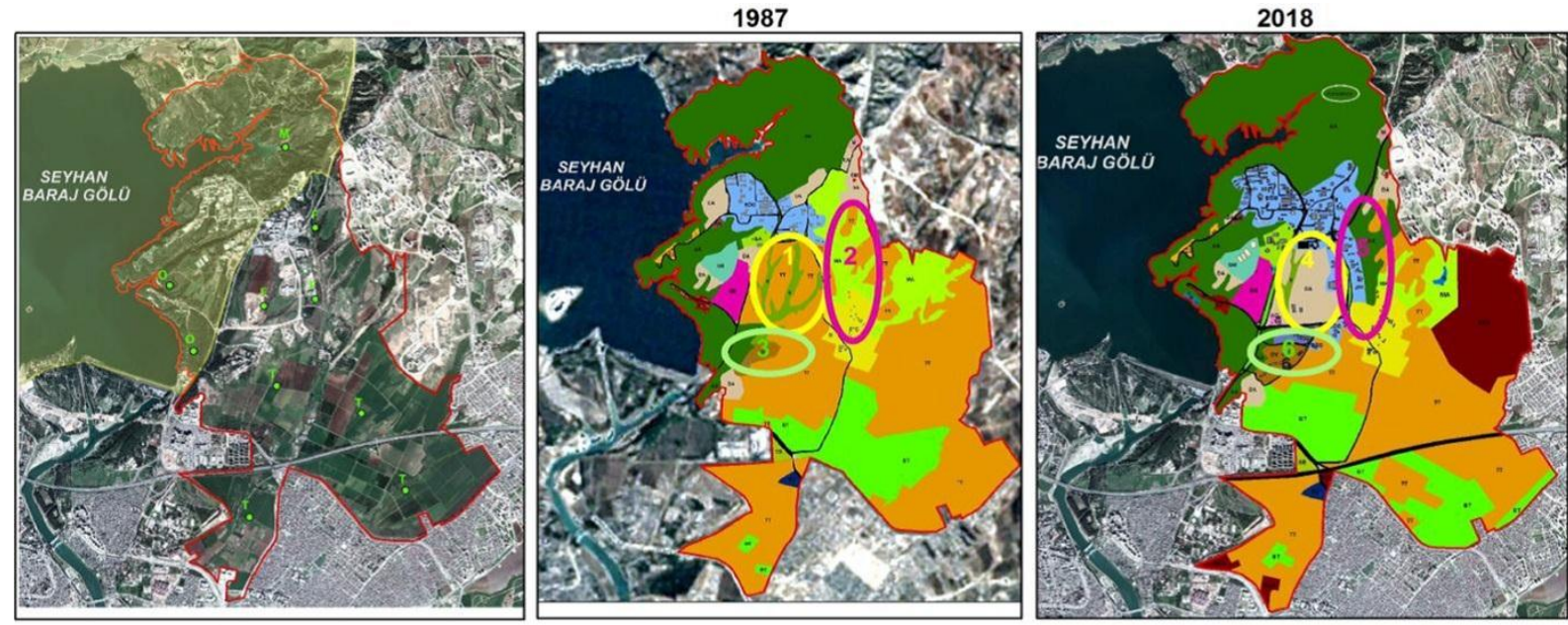

\begin{tabular}{|c|c|c|}
\hline & Maki & Çalışma Alanı Sının \\
\hline $\mathbf{F}$ & Frigana & Moikiyet Dışına Çıkan Alanlar (MÇA) \\
\hline o & Orman & Eğitim-Oğretim Dokusu (EOD) \\
\hline $\mathbf{T}$ & Tarm & Yaban Hayatı Geliştirme Sahası \\
\hline
\end{tabular}

\begin{tabular}{|lll|}
\hline $\mathbf{1}$ & Frigana & Vadiler ve tarm alanları \\
$\mathbf{2}$ & Frigana & Tarm ve mera alanları \\
3 & Tarmm ve eski ögrenci yurt alanlan \\
$\mathbf{4}$ & Frigana Teknokent, anaolulu, yeni kampüs \\
$\mathbf{5}$ & Frigana Yeni kampüs \\
6 & Yeni oggrenci yurtlan \\
\hline
\end{tabular}

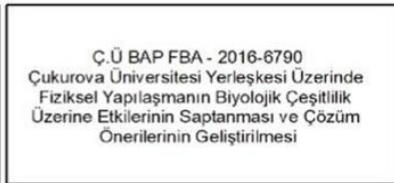

Şekil 7. Yerleşke florası için önemli habitatların yapılaşma baskısı ile değişimi

Şekil 7'de görülen 3 nolu alan ise eski öğrenci yurtlarının olduğu alan olup, bu alan çevresi tarım alanları olarak kullanılmaktaydı. Ancak günümüzde artan öğrenci sayısı gereksinimleri doğrultusunda yeni yurtları inşaatı ve Teknokent yapısal alanları ile bu terkedilmiş tarım alanlarındaki (Şekil 7'deki 6 nolu alan) florayı da geri dönülemez şekilde yok etmiştir.

Yerleşkenin yapılaşma süreci devam etmektedir. Yeni fakülte inşaatları Şekil 7'deki 5 nolu alanın güneyine doğru devam etmektedir. Bir diğer ifadeyle yapılaşma süreci başta frigana olmak üzere, terkedilmiş ve/veya mevcutta halen tarım yapılmakta olan alanlarda devam etmektedir. $\mathrm{Bu}$ durumun da mevcut flora üzerindeki baskıyı arttırması kaçınılmazdır.

Synantropik türler, genellikle kozmopolit ve tahribata dirençli oldukları için toprak yüzeyleri betonla kaplanmadığı sürece varlıklarını devam ettirebilmektedir. Non-synantropik türler ise hem endemik taksonları kapsamaları hem de antropojenik aktivitelere / tahribata dirençsiz olmaları nedeniyle koruma önlemlerinde ilk sirada yer almalıdır. Bu nedenle non-synantropik türlerin doğal habitatlarının (maki, frigana) ve terkedilmiş tarım alanlarının yerleşkede korunması, yerleşke florasinın sürdürülebilirliği için son derece önem taşımaktadır.

\section{TEŞEKKÜR}

Araştırmanın gerçekleştirilmesine maddi destekleriyle katkı sağlayan Çukurova Üniversitesi Bilimsel Araştırma Projeleri Koordinasyon Birimi'ne (Proje No: FBA_2016_6790) teşekkür ederiz.

\section{KAYNAKLAR}

Altunkasa F, Yücel M, Yılmaz KT, Atmaca M, Uslu C, İlter A 1999. Çukurova Üniversitesi Kampüsünde Fiziksel Planlamada Kullanılacak Verilerin Bilgisayar Yardımıyla Belirlenmesi. Çukurova Üniversitesi Ziraat Fakültesi Araştırma Projesi Proje No: BAP-PM-96/01, Adana.

Antipina, G. S, 2003. Urban Flora as a Component of the Urban Ecosystems in the Taiga Zone: An Example of Karelian Cities. Russian Journal of Ecology 34(4): 215-218.

Chape S, Harrison J, Spalding M, Lysenko I 2005. Measuring The Extent And Effectiveness of Protected Areas As An Indicator For Meeting Global Biodiversity Targets. Philosophical Transactions of the Royal Society B: Biological Sciences. http://doi.org/10.1098/rstb.2004.1592

Critical Ecosystem, 2017. Ecosystem Profile, Mediterranean Basin Biodiversity Hotspot. BirdLife International. https://www.cepf.net/sites/ 
default/files/mediterranean-basin-2017-ecosystemprofile-english_0.pdf (Erişim Tarihi: 07.03.2018).

Çepel N, 1982. Ek̄oloji Terimleri Sözlüğü, İ.Ü.Orman Fakültesi Yayınları No:3048/324 İstanbul.

Darıcı C, Sağlıker H., Kızıldağ N, Gül Dİ 2016. Çukurova Üniversitesi Kampüs Bitkileri. Adana. ISBN: 978-975-487-212-5.

Davis, PH 1965-1985. Flora of Turkey And The East Aegean Islands. Vols 1-9, Edinburgh University Press, Edinburgh.

Demirel Ö 2005. Doğa Koruma ve Milli Parklar. Karadeniz Teknik Üniversitesi, Genel Yayın No. 219, Fakülte Yayın No. 37, KTÜ Matbaası, Trabzon.

Ekim T, Koyuncu M, Vural M, Duman H, Aytaç Z, Adıgüzel N 2000. Türkiye Bitkileri Kırmızı Kitabı (Eğrelti ve Tohumlu Bitkiler). Türkiye Tabiatını Koruma Derneği ve Yüzüncü Yıl Üniversitesi, Ankara.

Güner A, Aslan S, Ekim T, Vural M, Babaç MT. (edlr.) 2012. Türkiye Bitkileri Listesi (Damarlı Bitkiler). Nezahat Gökyiğit Botanik Bahçesi ve Flora Araştırmaları Derneği Yayını.

Güner A, Özhatay, Ekim T, Başer KHC. (eds.) 2000. Flora of Turkey and The East Aegean Islands. Vol 11 (Supplement 2), Edinburgh University Press, Edinburgh.

Göçük S 1996. Çukurova Üniversitesi Kampüs Alanındaki Bazı Soğanlı, Yumrulu ve Rizomlu Bitkilerin Fenolojik Özellikleri. Çukurova Üniversitesi Fen Bilimleri Enstitüsü Peyzaj Mimarlığı Ana Bilim Dalı, Yüksek Lisans Tezi, 75 sy.

Gövrek A 1997. Çukurova Üniversitesi Kampüsü Doğal Potansiyelinin Belirlenmesi ve Biyotopların Haritalanması Üzerinde Bir Araştırma. Çukurova Üniversitesi Fen Bilimleri Enstitüsü Peyzaj Mimarlığı Ana Bilim Dalı, Yüksek Lisans Tezi, 57 sy.

Gülez S 1992. A Method for Evaluating Areas for National Park Status. Environmental Management, 16(6): 811-818.

Hummel C, Poursanidis D, Orenstein D, Elliott M, Adamescu MC, Cazacu C, Ziv G, Chrysoulakis N, van der Meer J, Hummel H 2019. Protected Area Management: Fusion and Confusion with the Ecosystem Services Approach. Science of The Total Environment, 651(2), 2432-2443. https://doi.org/ 10.1016/j.scitotenv.2018.10.033
IUCN 2016. Guidelines for Using the IUCN Red List Categories and Criteria. Version 12. Prepared by the Standards and Petitions Subcommittee.

IUCN 2012. Guidelines for Application of IUCN Red List Criteria at Regional and National Levels: Version 4.0. Gland, Switzerland and Cambridge, UK: IUCN. iii + 41pp. http://www.iucnredlist. org/documents/reg_guidelines_en.pdf.

Jackowiak B 1990. Anthropogenic Changes in The Flora of Vascular Plants of Poznań. Univ. A. Mickiewicz in Poznań, 208 pp.

Kaminski D 2006. Floristic Diversity on The Medieval Earthworks of Chelmo Land (Ziemia Chelminska) in North-West Poland. Biodiversity Research and Conservation 3(4): 344-347.

Liu J, Ouyang Z, Miao H 2010. Environmental Attitudes of Stakeholders and Their Perceptions Regarding Protected Area-Community Conflicts: A Case Study in China. Elsevier, Journal of Environmental Management 91(11): 2254-2262.

Lu M, Qu Y 2018. Biodiversity Conservation Development Based on Systematic Conservation Planning in Urban Areas. Energy Procedia, 153: 484-488. https://doi.org/10.1016/j.egypro.2018.10.027

Raunkiaer C 1934. The Life Forms of Plants and Statistical Plant Geography: Oxford at the Clarendon Press. https://archive.org/details/ in.ernet.dli.2015.271790 (Erişim Tarihi: 19.03.2018)

Tübives 2018. Türkiye Bitkileri Veri Servisi. http:// www.tubives.com/ (Erişim Tarihi: 19.03.2018).

Türe C, Böcük H 2010. Distribution Patterns of Threatened Endemic Plants in Turkey: A Quantitative Approach for Conservation. Journal for Nature Conservation 18: 296-303.

Türkmen N 1987. Çukurova Üniversitesi Kampüs Alanının Doğal Bitkileri, Hayat Formları ve Habitatları. Çukurova Üniversitesi Fen Bilimleri Enstitüsü Biyoloji Ana Bilim Dalı, Yüksek Lisans Tezi, 201 sy.

Ünal Ö 1995. Ç.Ü. Kampüsü Ağaçlandırma Alanındaki Alt Örtünün Bitki Sosyolojisi Yönünden İrdelenmesi. Çukurova Üniversitesi Ziraat Fakültesi Peyzaj Mimarlığı Bölümü, Lisans Tezi, 117 sy.

Yücel M 2005. Doğa Koruma. Çukurova Üniversitesi, Ziraat Fakültesi, Genel Yayın No:265, Ders Kitapları Yayın No: A-85, Adana. 